\title{
PENGARUH PENGGUNAAN MESIN CNC ROUTER TERHADAP WAKTU STANDAR PENGERJAAN ORNAMEN DESAIN INTERIOR
}

\author{
Adi Nugroho ${ }^{1^{*}}$, Sujadi $^{2}$ \\ ${ }^{1}$ Progam Studi Teknik Industri Universitas Universal, ${ }^{1}$ Kompleks Maha Vihara Duta Maitreya Bukit \\ Beruntung, Sei Panas Kota Batam Kepulauan Riau \\ ${ }^{2}$ Alumni Progam Studi Teknik Industri Universitas Putera Batam, Batu Aji Kota Batam, Kepulauan Riau \\ *Email: aaddinugroho@gmail.com
}

\begin{abstract}
This study aims to determine the effect of using CNC routers on the standard production time of ornament products at PT Victory Synergy. CNC itself is a machine that is controlled through numeric and letter codes (numerics) which consists of three main components, namely the computer, interface, and actuator system. The research method used in this study is a quantitative approach. Information or research data is obtained through observation, literature studies and interviews with production operators. Based on the results of measurements that have been done, it shows that the existence of $\mathrm{CNC}$ routers on the production floor was able to shorten the production stages that were previously carried out to reduce the production cycle time to reach 63.97 minutes or \pm 1 hour from the previous production process. This condition also proves that the design of these simple CNC routers can shorten the standard production time that occurs at PT Victory Synergy.
\end{abstract}

Keywords: CNC routers, ornamen

\section{Pendahuluan}

Pada dasarnya ornamen merupakan hiasanhiasan yang ditempatkan pada suatu tempat yang disesuaikan dengan keserasian situasi dan kondisi, baik berupa bentuk tekstur dan warna agar terlihat menarik bagi orang lain yang melihatnya. Ornamen ini dapat dilekatkan pada eksterior bangunan maupun interior bangunan, baik pada elemen arsitektur maupun elemen konstruksi (Dhanoe Iswanto, 2013) . Dalam ruang lingkup dunia arsitektur, ornamen merupakan hiasan yang digunakan pada bangunan, usaha yang berfungsi untuk menutupi atau menyamarkan bentuk asal dari suatu bahan atau struktur yang digunakan dalam bangunan tersebut. Ornamen dapat juga disebut pola hias yang dibuat dengan digambar, dipahat, dan dicetak, untuk mendukung meningkatnya kualitas dan nilai pada suatu benda atau karya seni. Ornamen juga merupakan perihal yang akan menyertai bidang gambar (lukisan atau jenis karya lainnya) sebagai bagian dari struktur yang ada di dalamnya (Putrie \& Hosiah, 2012). Dalam perkembangan, penciptaan karya seni ornamen tidak hanya dimaksudkan untuk mendukung keindahan suatu benda, namun juga mencerminkan semangat kreativitas seorang seniman sebagai karya seni yang berdiri sendiri, tanpa harus menumpang atau mengabdi pada kepentingan lain.
Salah satu contoh usaha yang bergerak dalam bidang pembuatan produk seni ornamen di Kota Batam yaitu PT. Victory Synergy. Perusahan yang berada di daerah batu besar Kota Batam sampai saat ini masih menggunakan peralatan manual dalam melakukan kegiatan produksinya. Kondisi tersebut dapat dilihat pada proses pemotongan motif ornamen, dimana peralatan yang digunakan hanya berupa mesin scroll saw. Dalam pelaksanaannya, penggunaan alat potong manual menggunakan alat scroll saw sering mengalami kesalahan. Hal ini terjadi pada hasil potong yang tidak sesuai ukuran dan bentuk yang diharapkan. Kondisi ini tentu dapat menyulitkan pekerja karena membutuhkan ketelitian tangan seorang operator. Selain itu proses pemotongan juga memerlukan waktu yang cukup lama hingga mencapai waktu 16 jam dan juga terdapat beberapa proses yang di golongkan kedalam proses yang tidak bernilai tambah (non value added) yang meliputi disain bagian produk menggunakan komputer kemudian hasil desain harus di cetak di media banner/kertas yang kemudian hasil dicetak banner/kertas ditempelkan pada media sebagai mall untuk melukis/menggambar motif pada media. Setelah media selesai di lukis/digambar motif ornamen kemudian dilanjutkan kegiatan pemotongan menggunakan mesin scroll saw, yang selanjutnya dilakukan pemasangan dan finishing ornamen pada tempat yang telah di tentukan. 
Langkah-langkah tersebut menggunakan material spon berukuran $1 \mathrm{~m}^{2}$ yang membutuhkan waktu kurang lebih selama 36 jam. Proses pemotongan bahan mengikuti motif-motif yang telah dibuat menggunakan mesin scroll saw merupakan proses yang paling lama hingga mencapai waktu16 jam atau \pm 2 hari. Sedangkan untuk material kayu triplek untuk ukuran $0,5 \times 0,5$ $\mathrm{m}^{2}$ dengan ketebalan $8 \mathrm{~mm}$ membutuhkan total waktu \pm 2 jam. Kondisi ini tentu saja mengakibatkan kegiatan produksi menjadi tidak optimal, disebabkan sumber daya hanya dihabiskan untuk menyelesaikan satu kegiatan saja. Apalagi dalam menghadapi permintaan yang terus meningkat dan motif-motif yang beragam, memaksa perusahaan harus melempar pekerjaan pemotongan keperusahaan lain yang memiliki mesin $C N C$ router yang menetapkan hingga mencapai $\mathrm{Rp} 500.000 / \mathrm{m}^{2}$. Kondisi ini tentu saja menambah beban pengeluaran bagi perusahaan yang sedang berusaha untuk mengejar efisiensi dan efektifitas proses produksinya. Berdasarkan penjelasan tersebut, penelitian ini berusaha untuk membantu pihak PT. Victory Synergy mengurangi beban biaya operasional produksi melalui perancangan mesin CNC router sederhana yang berfungsi untuk memotong material ornamen secara otomatis. Dari hasil penelitian yang akan dilakukan diharapkan dapat mengurangi waktu proses produksi yang terjadi dalam pembuatan produk ornamen di PT. Victory Synergy.

\section{Landasan Teori}

Berkembangknya teknologi informasi saat ini, ternyata telah memberi pengaruh yang cukup besar diberbagai bidang industri jasa dan manufaktur, tanpa terkecuali industri ornamen. Hasil pencapaian tersebut dapat dilihat dari berbagai hasil penemuan-penemuan yang mampu mengubah cara pandang manusia terhadap sesuatu yang sulit menjadi mudah dan tidak mungkin manjadi mungkin untuk dilakukan. Salah satu hasil kemajuan tersebut ditandai dengan ditemukannya produk mesin CNC yang telah berkembang dibeberapa tahun terakhir. Mesin yang banyak digunakan dalam berbagai jenis industri ini telah cukup banyak membantu manusia dalam melakukan aktifitas kegiatan produksi. Mesin CNC (Computer Numerically Controlled) merupakan mesin yang dikontrol oleh komputer menggunakan bahasa numerik (data perintah dengan kode angka, huruf dan simbol) yang telah disusun berdasarkan standar ISO (Sudarno, Martono, 2016). Mesin CNC memiliki dua atau lebih arah gerakan tool yang disebut dengan sumbu atau axis. Gerakan pada axis antara lain linier (yang merupakan garis lurus) atau gerakan circular (yang merupakan lintasan melingkar). Umumnya, sumbu yang terdapat pada gerakan linier adalah $\mathrm{X}$, Y dan $\mathrm{Z}$ sedangkan nama axis pada gerakan circular adalah A, B (Amala \& Widyanto, 2014)

Bukan hanya sekedar berfungsi untuk membentuk pola sesuai kebutuhan, mesin ini juga mampu memberikan tingkat akurasi dan presisi yang cukup baik jika dibandingkan mesin-mesin perkakas pada umumnya. Hal tersebut dikarenakan CNC telah didukung oleh beberapa komponen hardware canggih dan software pendukung untuk menjalankan fungsinya dengan baik. Beberapa kegiatan penelitian yang telah dikembangkan terkait dengan mesin CNC (Computer Numerically Controlled) diantaranya, perancangan desain sistem kendali router berbasis computer numerical control (CNC) menggunakan personal computer $(P C)$, yang di implementasikan pada flame cutting machine (FCM) (Roni, dkk, 2011). Selain itu, penelitian yang mencoba merealisasikan CNC Milling Machine Home Made dengan pengendali menggunakan komputer yang dijalankan oleh sebuah program untuk membuat layout PCB (Dityo Kuriawan P, 2011). Rancang bangun CNC Milling Machine Home Made memiliki dimensi yang tidak terlalu besar yaitu dimensi $30 \mathrm{~cm}$ x $50 \mathrm{~cm}$ x $40 \mathrm{~cm}$ dan memiliki berat $6,5 \mathrm{Kg}$. Mesin tersebut juga memiliki tingkat akurasi yang baik. Penelitian lain yang juga berhasil dikembangkan yaitu tentang optimalisasi parameter pada pemrogaman $\mathrm{CNC}$ milling berbasis CAD/CAM (Yudhayadi. dkk, 2016). CAD atau Computer Aided Design adalah suatu program komputer untuk menggambar suatu produk yang digambarkan oleh garis-garis maupun simbolsimbol yang memiliki makna tertentu. $C A D$ bisa berupa gambar dua dimensi dan gambar tiga dimensi. CAM (Computer-Aided Manufacturing) merupakan proses selanjutnya dibantu computer setelah computer aided design(CAD). Model yang dihasilkan dalam $C A D$ lalu diverifikasi untuk dapat masukan ke dalam perangkat lunak CAM, yang kemudian mengontrol mesin.(Setyoadi et al., 2015). Selain itu, penelitian juga telah mencapai pengukuran ketelitian perangkat lunak yang digunakan pada sistem operasi CNC (Mushafa, 2014). Proses kalibrasi dilakukan pada sumbu gerak $\mathrm{X}, \mathrm{Y}$ dan $\mathrm{Z}$ dengan menghasilkan nilai penyimpangan sebesar $0,01 \mathrm{~mm}$.

\subsection{Peran CNC Router pada Aktifitas Pembuatan Ornamen}

Pada aktifitas pembuatan ornamen, mesin CNC router memiliki peran sebagai alat bantu kerja pada proses pemotongan bahan. Baik 
bahan yang akan dipakai langsung untuk ornamen maupun bahan yang akan dijadikan cetakan bentuk ornamen. Mesin router pada mulanya diciptakan untuk memotong bentuk profil sederhana pada kayu menggunakan tangan. Penggunaan pisau potong dapat disesuaikan dengan material yang akan di gunakan. Sebagai contoh, untuk pengerjaan bahan kayu, aluminium, PVC, plastik bisa menggunakan pisau potong jenis HSS sedangkan untuk matrial keramik dan kaca menggunakan pisau potong jenis diamond.

\subsection{Pengukuran Kerja dengan Jam Henti (Stop-watch time study)}

Pengukuran waktu dengan jam henti (Stopwatch time study) diperkenalkan pertama kali oleh Frederick W. Taylor sekitar abad ke-19 yang lalu. Metode ini sangat cocok diaplikasikan pada pekerjaan yang berlangsung secara singkat dan berulang-ulang. hasil pengukuran maka akan diperoleh waktu baku untuk menyelesaikan suatu siklus pekerjaan, yang mana waktu ini akan dipergunakan sebagai standar penyelesaian pekerjaan bagi semua pekerja yang akan melaksanakan pekerjaan yang sama seperti itu.

Pengukuran kerja dengan Jam henti (Stop-watch time study) merupakan teknik pengukuran kerja dengan menggunakan Stop-watch sebagai alat pengukur waktu yang ditunjukan dalam penyelesaian suatu aktivitas yang diamati (Wignjosoebroto, 2008). Waktu yang berhasil diukur dan dicatat kemudian dimodifikasi dengan mempertimbangkan tempo kerja operator dan menambahkan kelonggaran waktu (allowance).

Untuk menghitung waktu baku dengan pengukuran kerja dengan jam henti (Stop-watch time study) terdapat langkah langkah yang sebaiknya dilakukan, yaitu:
1) Menentukan Performance rating operator
2) Menentukan waktu normal
3) Menentukan kelonggaran (allowance)

\subsection{Penyesuaian Waktu dengan Rating Performance}

Merupakan aktivitas yang digunakan untuk menilai atau mengevaluasi kecepatan kerja operator. Ketidak normalan waktu kerja diakibatkan oleh operator yang bekerja secara kurang wajar yaitu bekerja dalam tempo atau kecepatan yang tidak sebagaimana mestinya. Suatu saat dirasakan terlalu cepat dan disaat lain terlalu lambat. Rating performance adalah satu persoalan penilaian yang merupakan bagian dari aktivitas pengukuran kerja dan untuk menetapkan waktu baku penyelesaian kerja maka faktor penilaian (cenderung bersifat subyektif) terhadap tempo kerja operator ini harus dibuat oleh Time study analyst. Untuk menormalkan waktu kerja yang diperoleh dari hasil pengamatan, maka hal ini dilakukan dengan mengadakan penyesuaian yaitu dengan cara mengalihkan waktu pengamatan rata rata dengan faktor penyesuaian (rating performance) (Wignjosoebroto, 2008).

Menyatakan asumsi kondisi operator berdasarkan nilai faktor penyesuaian (rating performance) dapat ditentukan melalui penjelasan sebagai berikut :

1) Apabila operator dinyatakan terlalu cepat, yaitu bekerja diatas batas kewajaran (normal) maka faktor penyesuaian ini akan lebih besar dari pada satu $(\mathrm{Pf}>1$ atau $\mathrm{Pf}>100 \%)$

2) Apabila operator dinyatakan terlalu lambat, yaitu bekerja diatas bawah kewajaran (normal) maka faktor penyesuaian ini akan lebih kecil dari pada satu ( $\mathrm{Pf}<1$ atau $\mathrm{Pf}<100 \%)$

3) Apabila operator bekerja secara normal, maka faktor penyesuaian ini diambil sama dengan waktu ( $\mathrm{Pf}=1$ atau $\mathrm{Pf}=$ $100 \%)$.

\subsection{Waktu Normal dan Waktu Standar}

Waktu normal adalah waktu yang diperlukan oleh seorang operator yang terlatih yang memiliki keterampilan rata-rata untuk melaksanakan suatu aktivitas dibawah kondisi dan tempo kerja normal (Wignjosoebroto, 2008). Pengukuran yang digunakan untuk menghitung waktu tersebut dapat menggunakan rumus perhitungan sebagai berikut :

Waktu Normal $=$ Total Waktun $x$ Performa rating (\%)

Sedangkan waktu standar adalah waktu yang dibutuhkan oleh pekerja yang memiliki tingkat kemampuan rata rata untuk menyelesaikan suatu pekerjaan. Waktu standar tersebut sudah mencakup kelonggaran waktu (allowance time) yang diberikan dengan memperhatikan situasi dan kondisi yang harus diselesaikan (Wignjosoebroto, 2008).

Waktu standar $=$ waktu normal + allowance $(\%)$

\section{Metodologi Penelitian}

Penelitian ini menggunakan teknik kuantitatif sebagai dasar untuk melakukan perancangan mesin CNC sederhana. Mulai dari perhitungan kebutuhan komponen alat sampai pengolahan data hasil pengujian produk mesin CNC. Pengumpulan data atau informasi 
menggunakan tiga teknik yaitu observasi, wawancara dan studi literatur. Observasi digunakan untuk memperoleh informasi aktual kegiatan penelitian yang dilakukan melalui aktifitas pengamatan. Wawancara digunakan untuk memperoleh informasi pendukung mengenai kondisi terkini yang terjadi pada objek penelitian. Sedangkan studi literatur digunakan untuk memperoleh informasi mengenai kekinian kegiatan penelitian yang telah dilakukan sebelumnya. Secara detail, langkah-langkah

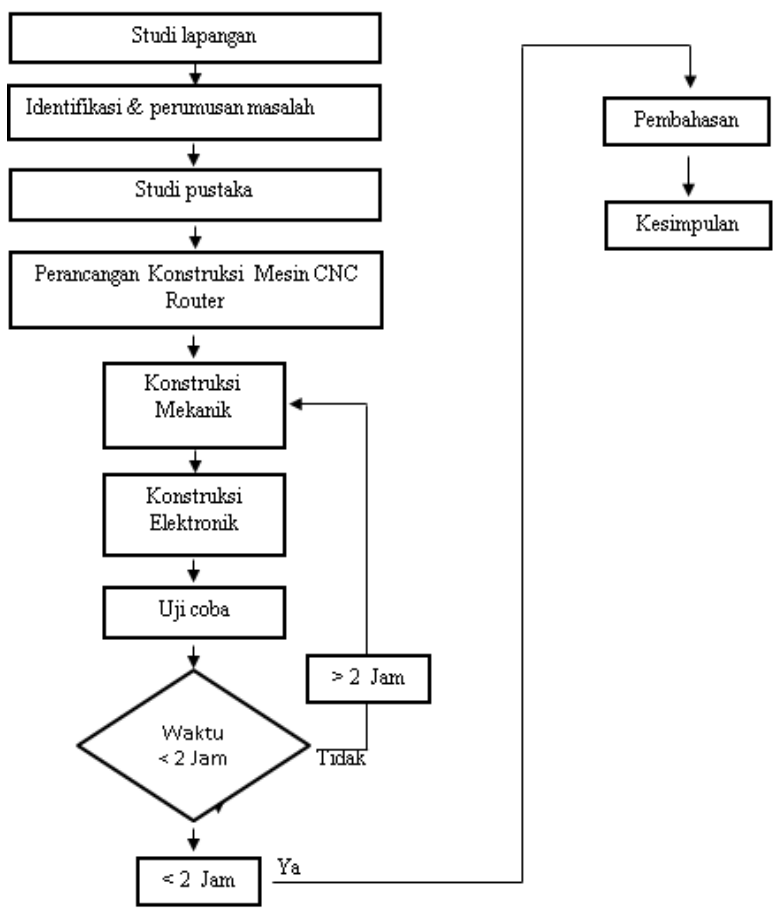

kegiatan penelitian dapat dilihat pada Gambar 1

Gambar 1. Langkah-langkah Penelitian

\subsection{Sampel dan Analisis Data}

Sampel material yang di gunakan penelitian ini yaitu untuk produk ornamen dengan bahan dasar plat aluminium ukuran $0,5 \mathrm{~m}^{2}$ yang memiliki ketebalan sebesar 0,5 mm. kelengkapan data mengacu pada uji kecukupan dan keseragaman data yang dapat ditentukan menggunakan rumus: Uji kecukupan data

$$
\mathrm{N}^{\prime}=\left(\frac{\left(k / s \sqrt{\mathrm{N} \sum \mathrm{X}_{i}^{2}-\left(\sum \mathrm{X}_{i}\right)^{2}}\right)}{\sum \mathrm{X}_{i}}\right)^{2}, \mathrm{~N}>\mathrm{N}^{\prime}
$$

Dimana:

$\mathrm{N}^{\prime}=$ Jumlah pengamatan yang seharusnya dilakukan.

$\mathrm{k}$ = Tingkat kepercayaan dalam pengamatan. $(\mathrm{k}=2,=95 \%)$

$\mathrm{s}=$ Derajat ketelitian dalam pengamatan.
$(10 \%)$

$\mathrm{N}$ = Jumlah pengamatan yang sudah dilakukan.

$\mathrm{X}_{i}=$ Data pengamatan .

Uji keseragaman data

$\bar{X}=\frac{\sum \mathrm{Xi}}{\mathrm{N}}$

$\mathrm{s}^{2}=\sum \frac{(\mathrm{xi}-\overline{\mathbf{X}})^{2}}{\mathrm{n}-1}$

$s=\sqrt{\mathrm{s}^{2}}$

$\mathrm{BKA}=\overline{\mathrm{X}}+(\mathrm{k} \cdot \mathrm{s})$

$\mathrm{BKB}=\overline{\mathrm{X}}-(\mathrm{k} \cdot \mathrm{s})$

Dimana :

$\mathrm{BKA}=$ Batas control atas

$\mathrm{BKB}=$ Batas control bawah

$\mathrm{n} \quad$ = Jumlah data pengamatan

$\mathrm{X}_{\boldsymbol{i}} \quad=$ Data pengamatan

$\overline{\mathrm{X}} \quad=$ Nilai rata-rata

$\mathrm{s}^{2} \quad=$ Sampel varian

$\mathrm{S} \quad=$ Standar deviasi

$\mathrm{k}=$ Tingkat keyakinan

\subsection{Spesifikasi Produk}

Perancangan desain mesin $\mathrm{CNC}$ router menggunakan aplikasi software google sketcup 8 yang mempunyai ukuran panjang rangka meja mesin $1000 \mathrm{~mm}$, lebar $700 \mathrm{~mm}$ dan tinggi 800 mm. Ukuran tersebut akan membentuk area kerja yang dapat di gunakan sebesar $700 \mathrm{~mm}$ untuk sumbu X, $400 \mathrm{~mm}$ untuk sumbu Y dan $100 \mathrm{~mm}$ untuk sumbu Z. Rangka mesin menggunakan besi Hollow ukuran 50x50x3mm, hal ini mengingat material tersebut banyak tersedia di pasaran dan harganya relatif murah.

Motor penggerak aktuator sumbu X,Y,Z menggunakan motor stepper bi-polar, NEMA 23 (National Electrical Manufacturers Association) dengan 2 phase, torsi $3,2 \mathrm{~N} / \mathrm{m}, 1.8^{0}$ /step, 4 Ampere Linier motion yang di gunakan model LWL 15 Produk IKO Japan. Spindel utama mesin menggunakan trimer Fujiyama model TM9700, 710 Watt, 10000-30000 rpm. Ballscrew yang digunakan diameter $16 \mathrm{~mm}$ dengan phich $10 \mathrm{~mm}$. Mata pahat yang akan di gunakan jenis carbid enmill diameter $6 \mathrm{~mm}$ Driver motor stepper yang digunakan 3 axis TB 6560-3A Software yang digunakan untuk kontrol mesin adalah Mach 3

Kontruksi mekanik akan melalui beberapa proses diantaranya, pembuatan rangka mesin, pembuatan pembuatan penggerak sumbu $\mathrm{X}$, pembuatan penggerak sumbu $\mathrm{Y}$, pembuatan penggerak sumbu Z. Sistem penggerak sumbu menggunakan ball screw. Agar diperoleh tingkat akurasi yang baik dilakukan pemasangan spindel utama. 


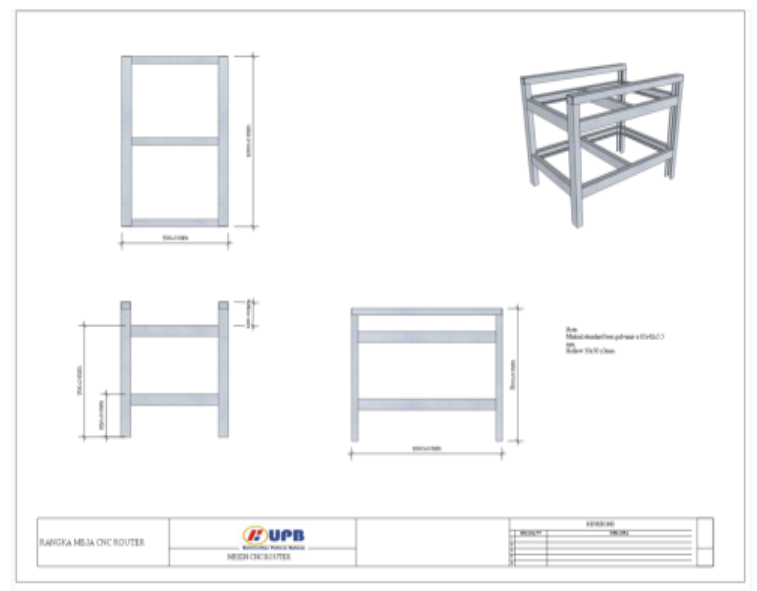

Gambar 2. Rangka mesin $\mathrm{CNC}$ router

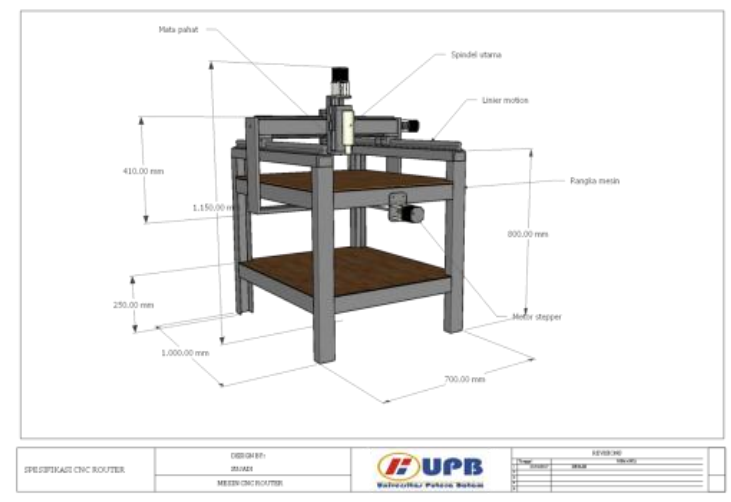

Gambar 3. Spesifikasi mesin $C N C$ router

Sedangkan konstruksi elektronik meliputi beberapa proses utama yaitu pemasangan power suplay dan driver motor, pemasangan terminal motor, pemasangan motor stepper sumbu $\mathrm{X}$, pemasangan motor stepper sumbu Y, pemasangan motor stepper sumbu $\mathrm{Z}$, Pemasangan motor spindel, Instalasi software Mach 3.

\section{Hasil Penelitian}

\subsection{Konstruksi mesin $\mathrm{CNC}$ router}

Perakitan komponen mesin dilakukan secara bertahap. Mulai dari penyusunan kerangka sampai pada tahap pengujian.

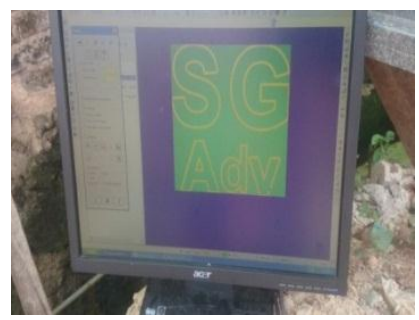

Gambar 4. Proses Desain

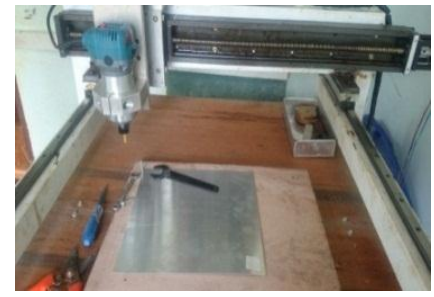

Gambar 5. Proses Penyetingan

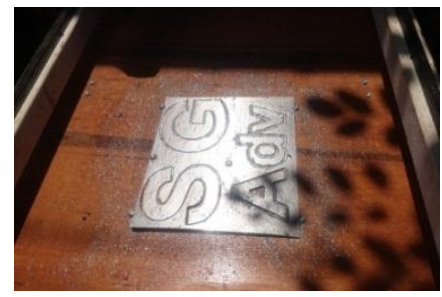

Gambar 6. Proses Pemotongan

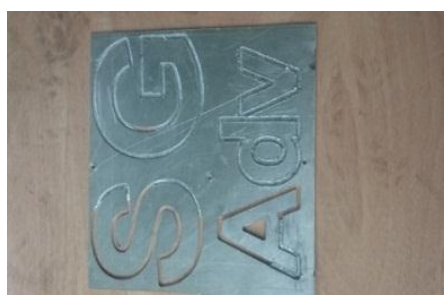

Gambar 7. Proses Finishing

Untuk mengetahui konsistensi performance mesin, penelitian melakukan beberapa kali pengujian secara berulang pada contoh produk dan material yang sama. Pengujiann juga mempertimbangkan aspek usaha, konsistensi, kondisi kerja dan keterampilan operator yang ditentukan berada pada level good (baik).

\subsection{Perbandingan waktu proses}

Perbedaan selisih waktu kerja yang dibutuhkan oleh operator sebelum dan sesudah menggunakan mesin CNC dapat secara jelas dilihat pada Tabel 1 dan Tebel 2. 
Tabel 1 Pengukuran waktu kerja sebelum menggunakan mesin $\mathrm{CNC}$

\begin{tabular}{llclll}
\hline $\begin{array}{c}\mathbf{N} \\
\mathbf{0}\end{array}$ & Aktifitas & $\begin{array}{c}\overline{\mathbf{x}} \\
(\mathbf{m e n i t} \\
)\end{array}$ & $\mathbf{\Sigma X}^{\mathbf{2}}$ & $(\mathbf{\Sigma x})^{\mathbf{2}}$ & $\begin{array}{c}\mathbf{\Sigma}(\mathbf{x}- \\
\mathbf{\mathbf { x }})^{\mathbf{2}}\end{array}$ \\
\hline $\mathbf{1}$ & Desain & 34.7 & 729 & 4326 & 83.33 \\
& & & 4 & 4 & \\
\hline $\mathbf{2}$ & $\begin{array}{l}\text { Cetak } \\
\text { Desain }\end{array}$ & 19.0 & $\begin{array}{l}220 \\
6\end{array}$ & $\begin{array}{l}1299 \\
6\end{array}$ & 40.00 \\
\hline $\mathbf{3}$ & $\begin{array}{l}\text { Menggamb } \\
\text { ar }\end{array}$ & 23.3 & 328 & 1960 & 19.33 \\
& & 6 & 0 & \\
\hline $\mathbf{4}$ & Memotong & 34.0 & $\begin{array}{l}710 \\
0\end{array}$ & $\begin{array}{l}4161 \\
6\end{array}$ & 164.00 \\
& & & 0 & \\
\hline $\mathbf{5}$ & Finising & 14.2 & 122 & 7225 & 18.83 \\
& & & 3 & & \\
\hline & Total & $\mathbf{1 2 5 . 2}$ & & & \\
\hline
\end{tabular}

Tabel 1 menunjukan rankaian aktifitas yang harus dilalui dalam pembuatan produk ornamentdi PT. Victory Synergy. Aktifitas yang membutuhkan cukup lama terjadi pada kegiatan desain dan memotong yang mencapai lebih dari 200 menit. Hal ini dikarenakan dibutuhkan penyesuaian antara produk yang akan dibuat dengan keterbatasan sumber daya yang dimiliki oleh perusahaan. Semakin sulit model desain yang akan dibuat, maka waktu yang akan dibutuhkan juga akan semakin lama. Proses pencetakan desain/gambar yang seharusnya dapat digabungkan dengan gambar mau tidak mau harus dipisahkan dikarenakan berada dalam alat yang berbeda.

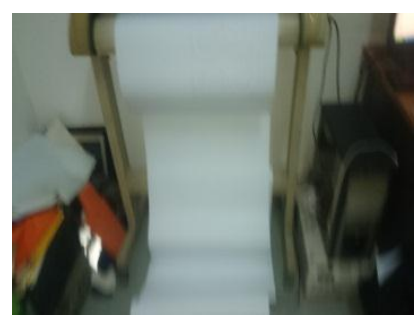

Gambar 8. Proses Pencetakan

Pada tabel 1, menunjukan waktu yang dibutuhkan untuk menyelesaikan satu desain produk ornament selama $\pm 125,2$ menit atau setara 2 jam.

$$
\begin{array}{ll}
\text { Perhitungan standar sebelum perancangan } \\
\text { Waktu Siklus (WS) } & =125,2 \text { menit } \\
\text { Penyesuaian (P) } & =1,06 \% \\
\text { Waktu Normal (WN) } & =125,2 \times 1,06 \% \\
& =132,71 \text { menit } \\
& =2,21 \mathrm{jam}
\end{array}
$$

Kelonggaran (K)

Waktu Baku (WB)

$$
\begin{aligned}
= & 9 \% \\
= & \mathrm{WN}+\% \text { allowance } \\
& \mathrm{X} \text { waktu normal } \\
= & 132,71+11,94 \\
= & 144,66 \text { menit }
\end{aligned}
$$

\begin{tabular}{|c|c|c|c|c|c|c|}
\hline $\begin{array}{l}\mathbf{N} \\
\mathbf{o}\end{array}$ & $\begin{array}{l}\text { Aktifit } \\
\text { as }\end{array}$ & $\Sigma \mathbf{x}$ & $\begin{array}{c}\overline{\mathbf{x}} \\
(\mathrm{meni} \\
\mathbf{t})\end{array}$ & $\Sigma X^{2}$ & $(\Sigma x)^{2}$ & $\begin{array}{l}\Sigma(\mathbf{x}- \\
\overline{\mathbf{x}})^{2}\end{array}$ \\
\hline 1 & Desain & $\begin{array}{c}19 \\
4 \\
\end{array}$ & 32.3 & $\begin{array}{r}633 \\
2 \\
\end{array}$ & $\begin{array}{r}3763 \\
6 \\
\end{array}$ & 59.33 \\
\hline 2 & Setting & $\begin{array}{c}13 \\
2 \\
\end{array}$ & 22.0 & $\begin{array}{r}293 \\
2\end{array}$ & $\begin{array}{r}1742 \\
4 \\
\end{array}$ & 28.00 \\
\hline 3 & Potong & 59 & 9.8 & 583 & 3481 & 2.83 \\
\hline 4 & $\begin{array}{l}\text { Finisin } \\
\mathrm{g}\end{array}$ & 34 & 5.7 & 200 & 1156 & 7.33 \\
\hline & Total & & 69.8 & & & \\
\hline
\end{tabular}

Berdasarkan informasi dari hasil pengukuran, diperoleh watu standar yang dibutuhkan operator untuk menyelesaikan produk ornamen dari awal hingga akhir selama 144,6 menit.

Tabel 2 Pengukuran waktu kerja sesudah menggunakan mesin $\mathrm{CNC}$

Tabel 2 menunjukan waktu yang dibutuhkan untuk menyelesaikan produk ornament dari proses awal hingga akhir hanya membutuhkan waktu selama $\pm 69,8$ menit. Jika dibandingan sebelum menggunakan mesin CNC router, waktu proses ini jauh lebih cepat 55,4 menit dari waktu proses sebelum menggunakan mesin CNC routers. Salah satu penyebabnya yaitu, terjadinya proses penggabungan dua aktifitas yaitu aktifitas mencetak dan menggambar. Penggabungan kedua aktifitas ini dilakukan karena fleksibilitas mesin $\mathrm{CNC}$ routers yang mampu untuk melakukan proses menggambar dan mencetak dalam satu tempat dengan waktu yang relatif singkat. Berdasarkan pencapaian ini maka waktu standar pembuatan produk ornament dapat diipercepat hingga mencapai 80,69 menit.

\section{Perhitungan standar setelah perancangan}

Waktu Siklus (WS) = $\quad$ 69,8 menit

Penyesuaian $(\mathrm{P}) \quad=1,06 \%$

Waktu Normal (WN) $\quad=69,8 \times 1,06 \%$

Kelonggaran $(\mathrm{K}) \quad=9 \%$

Waktu Baku (WB)= $=\mathrm{WN}+\%$ allowance

$\mathrm{x}$ waktu normal

$=74,02+6,66$

$=80,69$ menit 
Berdasarkan hasil pengukuran waktu standar pembuatan produk ornament menggunakan mesin CNC routers, diperoleh nilai 80,69 menit. Perolehan nilai ini menunjukan ada selisih nilai waktu standar sebesar 63,97 menit dari perhitungan waktu standar sebelum menggunakan mesin CNC routers. Analisis ini menjelaskan bahwa penggunaaan mesin $\mathrm{CNC}$ routers ternyata mempu mempercepat waktu proses pembuatan produk ornamen. Namun perolehan nilai waktu standar ini tidak bersifat mutlak. Hal tersebut disebabkan variasi yang terjadi pada masing-masing desain produk yang akan dibuat (sesuai permintaan). Analisis ini juga menunjukan bahwa keberadaan mesin $\mathrm{CNC}$ routers dapat memperpendek alur tahapan siklus produksi yang terjadi, khususnya pada aktifitas mencetak desain dan menggambar sehingga dapat mempersingkat waktu produksi.

\section{Kesimpulan}

Berdasarkan hasil pengukuran yang telah dilakukan, menunjukan bahwa keberadaan mesin CNC routers pada aktifitas produksi yang ada di PT. Victory Synergy dapat mempercepat waktu proses (waktu standar) pembuatan produk ornamen.

\section{DAFTAR REFERENSI}

Amala, M., \& Widyanto, S. A. (2014). Pengembangan Perangkat Lunak Sistem Operasi Mesin Miling CNC, 2(3), 204 210.

Dhanoe Iswanto, A. B. S. (2013). Ornamentasi Rumah Tradisional Kudus, 13, 88.

Solihat, O., \& Sn, M. (2005). Dasar Dasar Desain Interior Pelayanan Umum III, (1982 57).

Pradana, D. K. (2011). Rancang Bangun CNC Milling Machinehome Made, 10(1).

Putrie, Y. E., \& Hosiah, A. (2012). Keindahan dan ornamentasi dalam perspektif arsitektur islam, 2(1).

Setyoadi, Y., Latifah.(2015). Integrasi Software CAD-CAM dalam Sistem Operasi Mesin Bubut CNC, 149-159.

Sudarno, Martono, S. M. (2016). Rancang Bangun Mesin CNC Router Berbasis Arduino, $X V(2), 51-55$.

Sugiyono. (2011). Metode Penelitian Kuantitatif, Kualitatif, dan $R \& D$ (XIII). Bandung: Alfabeta, CV Bandung.

Saputra, R. P., Muqorobin, A., Santoso, A., \& Purwanto, T. P. (2012). Desain dan Implementasi Sistem Kendali CNC Router Menggunakan PC untuk Flame Cutting
Machine. Journal of Mechatronics, Electrical Power, and Vehicular Technology, 2(1), 41.

Wignjosoebroto, S. (2008). Ergonomi Studi Gerak dan Waktu. Jakarta: PT. Guna Widya. 